\title{
Review \\ Fungi in Freshwaters: Prioritising Aquatic Hyphomycetes in Conservation Goals
}

\author{
Juliana Barros (D) and Sahadevan Seena *D
}

MARE-Marine and Environmental Sciences Centre, Department of Life Sciences, University of Coimbra, 3004-517 Coimbra, Portugal; julibatistabarros@gmail.com

* Correspondence: seena.sahadevan@gmail.com or seena.sahavedan@uc.pt

Citation: Barros, J.; Seena, S. Fungi in Freshwaters: Prioritising Aquatic Hyphomycetes in Conservation Goals. Water 2022, 14, 605. https://doi.org/10.3390/w14040605

Academic Editor: Jun Yang

Received: 30 December 2021 Accepted: 15 February 2022 Published: 16 February 2022

Publisher's Note: MDPI stays neutral with regard to jurisdictional claims in published maps and institutional affiliations.

Copyright: (C) 2022 by the authors. Licensee MDPI, Basel, Switzerland. This article is an open access article distributed under the terms and conditions of the Creative Commons Attribution (CC BY) license (https:// creativecommons.org/licenses/by/ $4.0 /)$.

\begin{abstract}
Deprivation of protection for aquatic hyphomycetes is disturbing because they are key players in freshwater ecosystems across the globe. To attain a more holistic conservation paradigm for biodiversity in freshwaters, it is necessary to broaden our ecological perception of microfungi, mainly in aquatic hyphomycetes. A considerable groundwork still needs to be accomplished in progressing towards conserving aquatic hyphomycetes. Overcoming the paucity of information regarding the rare and endangered species, biogeography and above all, a global biodiversity database, would be a significant contribution in the initiation of an overarching conservation strategy for aquatic hyphomycetes. Being aware that the biodiversity decline in freshwaters is alarming, here we seek to explore why biodiversity data of aquatic hyphomycetes are missing. This article closely examines the threats to the biodiversity of aquatic hyphomycetes and freshwater ecosystems. Moving forward, we advocate a structured approach to gaining a thorough understanding to embrace aquatic hyphomycetes biodiversity into the conservation strategies. Including aquatic hyphomycetes in the conservation objectives may attract more funding opportunities for global surveys to initiate a fungal inclusive conservation era. Fungal conservation ventures can profit from interdisciplinary collaborations and cutting-edge science and technology, leading to informed decision making for biodiversity assessment and management.
\end{abstract}

Keywords: microfungi; biodiversity; IUCN; CBD; conservation strategies; macrofungi

\section{Introduction}

Freshwaters comprise less than $3 \%$ of the total water on earth [1,2] and are home to more than 100,000 described species. Barely 0.006\% of the freshwaters are rivers [3] and streams constitute $80 \%$ of their networks [1,3]. Freshwater is vital for sustaining life on earth and providing crucial benefits for our survival and well-being (e.g., drinkable water, agriculture, power generation, sanitation and recreation) [4]. The ever-increasing demand for freshwaters makes them particularly vulnerable and consequently the most endangered ecosystems on the planet. Therefore, there is a growing need to strike a balance between fulfilling our basic needs and the conservation of aquatic ecosystems [5]. To date, billions of people around the globe have been and are still deprived of safe drinking water [6]. In addition, the recent coronavirus pandemic since 2019 emphasised an urgent need for adequate solutions to meet modern society's water needs while maintaining and protecting freshwater ecosystems' structure, functioning and biodiversity.

Biodiversity is fundamental to human well-being and health [7]; nevertheless, biodiversity loss is occurring at unprecedented levels. Alarmingly, 83\% of the described world freshwater species and 30\% of freshwater ecosystems have vanished since 1970 [8]. However, we have just begun to address the freshwater biodiversity concerns and recognise it as a priority for conservation strategies since the early 2000s [5,9-11]. Currently, around one-third of the freshwater biodiversity is at risk of extinction, owing to anthropogenic disturbances, such as over-exploitation [2], habitat loss [12], pollution discharge [5], 
and introduction of exotic species [13]. Moreover, the extinction of species is expected to exacerbate with the ever-increasing population and the ongoing climate change [6].

Fungi form a major share of global biodiversity; both macrofungi and microfungi constitute around 10 to $20 \%$ of the total species [14]. Generally, freshwater fungi are microscopic and do not bear any visible fruiting bodies [15]. Aquatic hyphomycetes (Ingoldian fungi, freshwater hyphomycetes or amphibious fungi) are a phylogenetically heterogeneous group of anamorphic microfungi abound in well-oxygenated freshwaters. They commonly occur on the decaying organic matter and release copious quantities of asexual spores (conidia) into the lotic habitats [16]. These spores are mainly tetraradiate or sigmoid in shape (Figure 1).

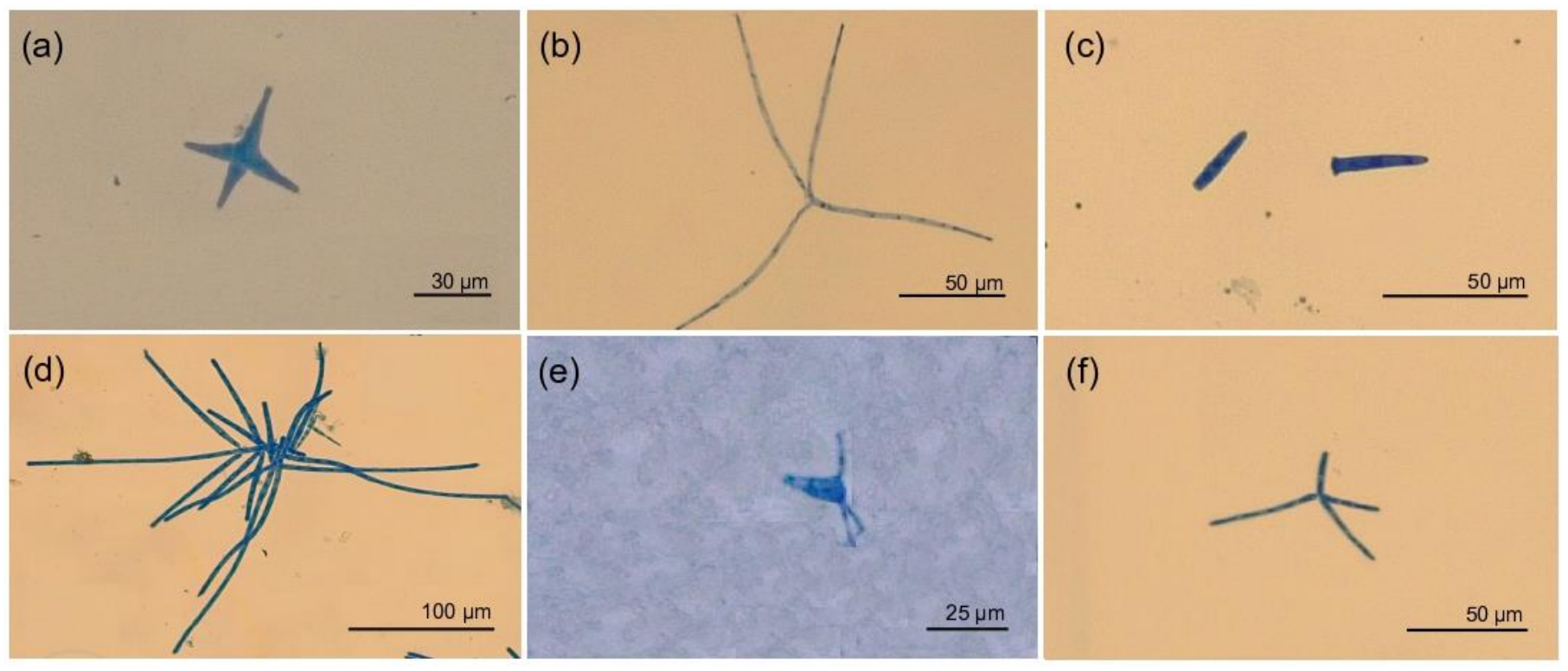

Figure 1. Spores (reproductive structures) of aquatic hyphomycetes, (a) Heliscella stellata, (b) Tetrachaetum elegans, (c) Neonectria lugdunensis, (d) Dendrospora erecta, (e) Clavariopsis aquatica and (f) Articulospora tetracladia.

Aquatic hyphomycetes were accidentally discovered in 1942 by Ingold while looking for chytrids [16]. They were greatly ignored until the limnologists realised the significant contribution of allochthonous organic materials to stream food webs [17]. Aquatic hyphomycetes play a paramount role in the decomposition of detritus through their enzymatic activities, consequently enhancing the palatability and nutritional quality of the litter for the invertebrates [18]. This activity facilitates the transfer of energy and nutrients to higher trophic levels $[18,19]$. With the advancement in taxonomic research, 335 morphospecies of aquatic hyphomycetes have been identified (for review, see Duarte et al. [20]), belonging mainly to Ascomycota with a small percentage attributed to Basidiomycota [21]. By the 2000s, growing evidence suggested that the aquatic hyphomycetes species richness or identity might influence the freshwater ecosystem processes $[22,23]$. This fundamental aspect restored the interest in the potential connection between aquatic hyphomycetes' biodiversity and freshwater ecosystem processes, health and integrity [23-27]. The ongoing global changes and anthropogenic impacts on the freshwaters have encouraged more insights into their biodiversity changes and occurrence in the little-explored regions across the globe [20].

Even though aquatic hyphomycetes are the cornerstone of the freshwater ecosystems' functional integrity and health [28], their conservation status is obscure. It is of utmost importance to systematically analyse their current status and future if conservation measures are to be administered. This approach will help to understand the knowledge gap and implement research into adequate management practices. Moreover, applying cuttingedge molecular techniques to identify aquatic hyphomycetes species and the ability to 
evaluate the entire fungal communities will enable researchers to determine and establish the trends in biodiversity and genetic patterns. These modern techniques, which favour species detection in the absence of reproductive structures, may open new avenues to fungal conservation.

The Convention on Biological Diversity (CBD) is the first global agreement to embrace all facets of biological diversity. The CBD targets incorporating all groups of organisms and conserving their biodiversity. They designated 2010 as the International Year of Biodiversity, but their logo demonstrated just plants and animals and in their official promotional video, fungi were not even mentioned. However, the conservation of macrofungi became global in 2019 and the macrofungal red list escalated from 66 to 280 (http:/ /iucn.ekoo.se/iucn/plans/; accessed on 28 December 2021). The International Union for Conservation of Nature's (IUCN) efforts to assess fungi is anticipated to focus on macrofungi (Ascomycetes and Basidiomycetes) in the future. Microfungi, including aquatic hyphomycetes, are orphaned in the Rio conventions, although many species may be endemic or even endangered. The global Red List initiative's gross marginalisation of these fungi impedes their inclusion in conservation discussions and meetings, funding initiatives, policy decision making and most importantly, conservation actions. Particularly with increasing knowledge on the role of aquatic hyphomycetes in freshwaters, raising awareness regarding their ecological importance and the necessity to conserve them is becoming increasingly more pivotal. Advancing the conservation vision of aquatic hyphomycetes can only be achieved by enhancing the coordination among the limnologists, mycologists and the broader conservation communities to foster strategies. Here, we first identify the threats to freshwater ecosystems and biodiversity of aquatic hyphomycetes. The impact of threats, such as hydrological alterations, agricultural activities, invasive species, climate changes and other major pollutants on aquatic hyphomycetes, is discussed. Second, we call attention to the fact that adequate knowledge on the biodiversity of aquatic hyphomycetes is missing, although the biodiversity decline in freshwaters is alarming. Third, we recommend a responsible approach towards understanding the biodiversity of all fungi, including aquatic hyphomycetes and embracing them in biodiversity conservation strategies. This approach will benefit scientists, mainly limnologists, mycologists, conservationists and a broader public, namely, policymakers, governmental and non-governmental organisations, other stakeholders and society.

\section{Threats to Freshwater Ecosystems and Biodiversity of Aquatic Hyphomycetes}

Globally over the past 100 years, freshwater demand has increased six-fold [29]. It is predicted that by 2030, water requirements may exceed $50 \%$ of its provisioning capacity [30]. Efforts have been mainly directed to 'ensure water availability for all' (Sustainable Development Goal 6), often neglecting biodiversity and ecosystem functioning of freshwaters. Most of the engineered solutions culminate in additional pressures on the ecosystem and significant changes in the global water cycle [31]. This exacerbated water necessity by modern human society may be primarily attributed to the combination of economic development, population growth and alterations in consumption patterns. The environmental changes due to these threats, such as modifications in $\mathrm{pH}$, carbon and nitrogen cycles, temperature, flow and runoff patterns [5], modulates the biodiversity of the impacted area, promoting shifts in species dominance and, most importantly, a decline in biodiversity.

It is a significant challenge among limnologists to determine how the environmental factors, including their overlaps, affect the relationship between biodiversity and ecosystem functioning [32]. Globally, aquatic hyphomycetes are common to fast-flowing unpolluted freshwaters [33]; they are sensitive to various environmental stresses altering their diversity, activity and community composition, compromising detrital food webs [34]. However, aquatic hyphomycetes are also evidenced to cope with a wide range of environmental stress, such as pollution or drought [33]. Thus, they are proposed as sensitive indicators for environmental changes and for risk assessment studies [35]. However, it is not evident whether the environmental stressors lead to the extinction of aquatic hyphomycetes species. 
Apart from the undeniable over-exploitation [2] of freshwaters, other anthropogenic factors responsible for the degradation of freshwater ecosystems and biodiversity of aquatic hyphomycetes are hydrological alterations, agricultural practices, invasive species, climate change and other pollutants [2].

\subsection{Hydrological Alterations}

Over the last century, rivers and streams have been heavily modified for human developmental purposes [36], resulting in an altered global water cycle. Hydrological alterations are the main abiotic factor governing freshwater ecosystems' structure, functioning and integrity [37]. It also determines the extent, depth and flow velocity of freshwaters, and consequently, the transport of nutrients and sediments. To date, barely $37 \%$ of rivers longer than $1000 \mathrm{~km}$ remain free-flowing throughout their entire length [10]. Dams have been constructed on most of the major rivers in the world [38], playing a pivotal role in modifying their flow and inundation patterns; for instance, Colorado, Ganges and Yellow Rivers have their flows heavily compromised by the construction of a large number of dams [5]. Dams also promote drought due to the diversion of water in the rivers [39]. Such modifications lead to alterations in habitat conditions and migration of species and matter cycling, such as carbon and nutrients [40]. Notably, damming of rivers regulates the biodiversity of aquatic hyphomycetes and their ecological processes [41]. A study conducted in 17 streams impacted by the presence of dams demonstrated that decomposition of organic matter decreased downstream due to alterations in the natural flow regime of streams. This could be attributed to the alterations in nutrient and carbon flow along the watercourse [42].

\subsection{Agricultural Practices}

Rivers and streams are profoundly linked to their surrounding terrestrial ecosystems $[19,43,44]$, owing to surface runoff and elemental cycling; hence, any activity that modifies terrestrial structure and composition will consequently impact freshwater ecosystems. Annually, around $70 \%$ of the available surface water is used only to sustain agricultural practices [45]. Agriculture also promotes the replacement of natural vegetation, thereby changing the riverine canopy, inputs of allochthonous organic matter, shading and water temperature, modifying the ecosystem structure and functioning. In addition, surface runoff from agricultural land may carry chemicals and fertilisers containing high levels of nutrients [5]. High nutrient loads alone or when accompanied by other environmental factors, such as temperature [46], are able to stimulate the growth of aquatic hyphomycetes $[34,47,48]$. The few available studies on the impacts of high nutrient loads on the aquatic hyphomycetes demonstrate that their response differs between species [49]. Besides nutrients, agriculture runoff carries large quantities of agrochemicals, such as pesticides [50], fungicides [50] and salts [51], with potential impacts on the biodiversity of aquatic hyphomycetes [52]. In general, the response of aquatic hyphomycetes to agrochemicals is species-specific and greatly depends on their chemical properties. A clear difference between the response of species to concentrations and types (herbicides and fungicides) has been observed when aquatic hyphomycete species were exposed to herbicides and fungicides in a previous study [50].

\subsection{Invasive Species}

Human activities have been destroying geographical barriers worldwide [53]; consequently, the boundaries between native and non-native species are likely to become blurred. The invasive riparian species may modify the habitat conditions, resulting in competition for resources and space. The replacement of riparian native vegetation by invasive species may impact the diversity of aquatic hyphomycetes and freshwater ecosystem functioning $[54,55]$. For instance, the richness of the aquatic hyphomycetes species was higher in the reference stream than in the stream surrounded by the invasive (Acacia) species affecting the leaf litter decomposition [56]. Exotic species may also contribute to ecosystem biodiversity by interacting or acting as functional homologs, sustaining important 
ecosystem services [57]. However, in most cases, when invasive species thrive, it causes vast disparities owing to the lack of predators, exploding their population at the expense of native species [58]. In addition, redistribution of native freshwater species is influenced by global climate change inducing the migration of species looking for more suitable habitats.

\subsection{Climate Changes}

Effects of climate change are numerous; for instance, an increase in temperature may accelerate the water evaporation rates, facilitating the forest fire or melting of ice, modifying streamflow and inundation patterns [59]. Studies demonstrate that freshwater ecosystems are becoming warmer, more acidic and less oxygenated [60]. If the water becomes too warm for the riverine species, they may probably disperse to cooler habitats, impeded by factors such as habitat availability and competition [5]. Regarding the streams, the climate change crisis is particularly more alarming, as the volume of water is lower than in large rivers; therefore, heating is much faster, compromising several vital ecological functions, such as groundwater recharge, nutrient cycling and biodiversity [61]. Furthermore, the measures taken to overcome climate change and water availability are likely to exacerbate biodiversity loss because it focuses mainly on fulfilling human needs by side-lining biodiversity [62]. Concerning aquatic hyphomycetes, the temperature is regarded as a vital environmental factor affecting their metabolic functions and ultimately, growth and survival [63]. Temperature fluctuations influence the abundance of aquatic hyphomycetes species and fungal community composition [63-65], affecting organic matter decomposition [66]. An efficient and sustainable water management framework should consider ecosystem-based approaches, ensuring the resilience and long-term stability of freshwaters [67].

\subsection{Other Major Pollutants}

Freshwaters are vulnerable to a wide range of pollutants [61], such as fossil fuels, metals, xenobiotics and synthetic hormones, negatively impacting the freshwater biota. The atmosphere is a sink of unwanted gaseous by-products originating mainly by the combustion of fossil fuels, released into the air as nitrogen dioxide, sulphur dioxide, carbon monoxide or hydrocarbons [68]. These contaminants are generally washed away by rain, making the freshwaters more acidic. It is demonstrated that co-exposures of acid rain and zinc oxide $(\mathrm{ZnO})$ nanoparticles could accelerate stream fungal community diversity and decomposition of organic matter [69].

Mining activities mobilise sediments, increase metal concentrations and modify water $\mathrm{pH}$ [2]. Metals may result in fungal biodiversity loss in freshwaters by reducing the occurrence of sensitive species [70,71]. Nonetheless, aquatic hyphomycetes have been reported from various metal-contaminated streams, probably due to their cellular tolerance and resistance mechanisms to cope with metals [72-76]. However, metal tolerance mechanisms demand substantial energy, which may affect their efficiency in reproduction, growth [73,77-79] and their functions (litter decomposition) [76].

Synthetic hormones found in birth control pills disrupt the endocrine systems of freshwater organisms such as invertebrates and fish [80]. Xenobiotic compounds, such as nonylphenols, which are widely used as a surfactant [81], may also act as endocrine disruptors by imitating natural hormones, blocking or inhibiting their production by the organisms [80]. In aquatic hyphomycetes, a low concentration of nonylphenols $\left(50 \mu \mathrm{g} \mathrm{L}^{-1}\right)$ enhanced their reproductive capacity [82]. In addition, antibiotics in the wastewaters may increase the resistance of the targeted organisms and may impact ecologically relevant nontargeted organisms [83]. However, aquatic hyphomycetes were not evidenced to be tolerant to antibiotics [84].

Furthermore, heat from industrial and power sector effluents [12] poses a significant threat to freshwater ecosystems [85]. The water retrieved from the watercourses to cool down a thermal plant is reverted to the river at much higher temperatures [86]. Temperature is one of the most important factors modulating the structure of aquatic 
hyphomycete communities [66], which may lead to severe consequences to freshwater ecological processes.

Recently, nanomaterials (nanoparticles and nanoplastics), plastisphere (microbial community established on microplastics) and microplastics have been considered as a predominant threat to freshwaters [75,87-90]. Increased release of nanomaterials into the freshwaters may induce shifts in aquatic hyphomycete communities with impacts on biodiversity and ecological processes [87]. In general, with an increasing concentration of nanomaterials in the freshwaters, the reproductive rate of aquatic hyphomycetes diminishes.

\section{Biodiversity Decline in Freshwaters Is Alarming but Adequate Knowledge on the Biodiversity of Aquatic Hyphomycetes Is Missing}

Besides critical benefits provided by freshwaters, such as the contribution to the economy (e.g., electricity or fishery) and provisioning of ecosystems services (e.g., drinkable water), freshwater biodiversity offers an irreplaceable global biodiversity databank [2,32]. It supports approximately $9.5 \%$ of the total species described $[2,12,62]$. In addition, $30 \%$ of the total freshwater species is comprised of vertebrates, including approximately 17,800 fish, 700 birds [85] and 250 turtle species [91]. It is well established that biologically diverse freshwater organisms confer adequate ecological resilience in the face of a changing environment [92]. However, we are yet to fully appreciate the biodiversity of fungi, including aquatic hyphomycetes in the freshwaters. The Freshwater Animal Biodiversity Assessment (FADA) [91] provides a large database on fish, reptiles, amphibians and some invertebrates [93]. It is evident that biodiversity assessment and conservation strategies focus on macro-organisms [94]. The studies on microbes relate mostly to their threats to larger organisms, rather than their biodiversity and conservation.

The IUCN Red List of Threatened Species provides only a partial cover of around 20\% of the known freshwater species [4]. Even so, this limited biodiversity coverage reveals that approximately $30 \%$ of the species assessed are categorised as threatened [4,85]. Amongst the threatened species, turtles (62\%), gastropods (47\%), mammals ( $42 \%)$, amphibians (33\%), decapods $(30 \%)$, fish $(28 \%)$ and birds $(20 \%)$ are at risk of extinction [85]. The most recent Living Planet Report 2020, derived from 3741 monitored populations of freshwater species (944 vertebrates), indicated a decline in their abundance by $84 \%$ in the last 50 years [8]. It suggests that the biodiversity loss in freshwater might be far more critical than what is documented.

In the 2000s, knowledge of freshwater biodiversity has increased [95]. It is estimated that around 2000 species of aquatic fungi are restricted to freshwaters [21,91]. To the best of our knowledge, the first and only initiative for biodiversity conservation of microfungi was undertaken via a project (2007-2010) funded by the UK Darwin Initiative attempting to conserve these vulnerable fungi in the terrestrial, freshwater and marine ecosystems. This project prioritised three specialist groups, namely: (1) non-lichen-forming Ascomycetes and conidial fungi, (2) rusts and smuts and (3) chromistans, chytrids, Myxomycetes and Zygomycetes. It is surprising that almost after 80 years of the discovery of aquatic hyphomycetes, there are no projects dedicated to assessing their global biodiversity. However, the occurrence of aquatic hyphomycetes, including the impact of environmental stressors, are well documented in some temperate regions [20]. Shortage of well-trained taxonomists, constraints in scientific capacity, accessibility to geographic regions and insufficient funds have restricted in-depth investigations. The lack of adequate knowledge regarding their biodiversity and distribution patterns [20] curtails the development of an adequate conservation plan. We are yet to appreciate the aquatic hyphomycetes species richness, patterns of biodiversity (alpha and beta), cosmopolitanism and endemism. There is also a need to distinguish rare species from endangered species; other aspects such as their distribution patterns and adaptations in the Anthropocene remain unexplored. Moreover, the biodiversity of aquatic hyphomycetes is greatly influenced by seasons demanding rigorous efforts throughout the year. The only study regarding the population genetics of aquatic hyphomycetes, spanning two years and two seasonal cycles, demonstrated that 
the genetic diversity of Tetracladium marchalianum varied significantly [96]. Additionally, a unique study along broad latitudinal gradient reveals that the species richness of aquatic hyphomycetes [97] and other aquatic fungi associated with leaf litter [65] peaked at midlatitudes and diminished further towards the extremes of the latitudinal gradient [97]. A compelling solution to improve our knowledge on a broader scale may be to create awareness among ecologists to cooperate and conduct coordinated studies across the globe.

\section{A Responsible Approach towards Understanding the Biodiversity of All Fungi, including Aquatic Hyphomycetes, Is Needed}

To date, the conservation status of most of the fungal species is unknown. Conservation agendas targeting fungi are mainly represented by macrofungi. They are distinguishable from other fungi by their visible spore-bearing fleshy fruiting body. To date, 425 macrofungal species have been evaluated by the IUCN Red List of Threatened Species [98]. Clearly, there is a tendency to protect visually noticeable and familiar species, severely reducing our focus on the global fungal extinction rate.

Invisible to the naked eye, microfungi make up the great majority of undescribed fungal taxa [15]. They are greatly present in our lives and economy. Although some microfungal species are pathogenic to plants and animals, compromising crops, livestock production and human beings, most microfungi are highly beneficial to our society. For example, the microfungi belonging to the genus Penicillium are the source of penicillin, a group of antibacterial drugs, which revolutionised the health care industry [15]. In addition, the food industry relies greatly on yeasts for the preparation of bread and beer $[15,99]$. Moreover, as eukaryotic organisms, yeasts are excellent model research organisms, ushering considerable advancements in modern genetics [15,99]. Most predominantly, microfungi are crucial to sustaining a wide range of ecosystem processes, maintaining life on the planet $[15,65]$. The most acknowledged is the mycorrhizal fungi, accomplishing a symbiotic partnership with approximately $90 \%$ of all plant roots [100]; these fungi facilitate the plants growth by improving the acquisition of nutrients from the soil; simultaneously the plant roots provide a reliable substrate for mycorrhizal fungal growth and reproduction [101]. In general, microfungi have impacted our environment for billions of years in a multitude of ways and are continuously touching millions of human lives. However, they need special attention because they are largely disregarded in the environment. Our lapse in estimating the biodiversity of the microfungi, including aquatic hyphomycetes, impedes their inclusion in the conservation goals. Taking steps towards filling this knowledge gap is pivotal to assisting efficient conservation policies and robust environmental management strategies to sustain freshwater ecosystems.

\section{Embracing Aquatic Fungi in the Freshwater Biodiversity Conservation Strategies}

The continuous degradation of freshwater ecosystems and the services they provide have led to the implementation of various international organisations and agreements (see Table 1), aiming to bend the curve of freshwater biodiversity loss [85]. Several biodiversity conservation organisations (Table 1) are involved in the data gathering and biodiversity analysis. The indicators produced by these projects are generally used to monitor biodiversity trends [102], raise awareness among the public and policymakers [103] and influence governments and other stakeholders by providing an unrestricted flow of information and advice. However, in most cases, due to inefficient management, the data gathered remain underutilised, confounding the development of data-driven policy decisions or the establishment of biodiversity conservation targets [104]. Despite supporting an impressive number of species and providing several irreplaceable ecosystem services, freshwater biodiversity is disproportionately under prioritised. Future strategies and actions should divert a greater focus on the distinctive ecology of freshwater organisms and their threats. More specifically, it is high time to acknowledge that we are yet to redirect our attention to an aquatic fungal inclusive conservation strategy. 
Table 1. International milestones in conservation strategies.

\begin{tabular}{|c|c|c|}
\hline Year & Milestone & Conservation Strategies \\
\hline 1948 & $\begin{array}{l}\text { International Union for the } \\
\text { Conservation of Nature (IUCN) }\end{array}$ & $\begin{array}{l}\text { - Union composed by approximately } 1400 \text { members (countries, } \\
\text { governments and civil organisations). } \\
\text { - It is mainly involved in data gathering, analysis and education. } \\
\text { To influence government, and stakeholders by providing information, } \\
\text { advice and partnerships. }\end{array}$ \\
\hline 1961 & $\begin{array}{l}\text { World Wildlife Fund for } \\
\text { Nature (WWF) }\end{array}$ & $\begin{array}{l}\text { - Organisation working in wilderness preservation and reduction of } \\
\text { human impact on the environment. } \\
\text { Responsible for publishing 'The Living Planet Report' every two years } \\
\text { since } 1998 \text {. }\end{array}$ \\
\hline 1964 & First edition of IUCN Red List & $\begin{array}{l}\text { - The world's most comprehensive catalogue of the global conservation } \\
\text { status of several biological species was published. }\end{array}$ \\
\hline 1971 & Green Peace & $\begin{array}{l}\text { - Independent global network aiming to safeguard environment } \\
\text { and biodiversity. } \\
\text { Focus on issues such as: climate change, deforestation, overfishing, } \\
\text { commercial whaling, genetic engineering and anti-nuclear materials. }\end{array}$ \\
\hline 1971 * & The Ramsar Convention on wetlands & $\begin{array}{l}\text { - First international agreement for conservation and sustainable use of } \\
\text { wetlands; it came into force in } 1975 \text {. } \\
\text { Representatives of the contracting parties meet every three years to } \\
\text { discuss achievements and further steps. }\end{array}$ \\
\hline 1972 & $\begin{array}{l}\text { United Nations Conference on the } \\
\text { Human Environment (Stockholm } \\
\text { Declaration) }\end{array}$ & $\begin{array}{l}\text { - Held in Stockholm, resulting in the beginning of an international } \\
\text { environmental law, alongside with the first agreement ( } 26 \text { principles and } \\
109 \text { recommendations) regarding environment, development, human } \\
\text { rights and protection of natural resources. }\end{array}$ \\
\hline 1972 & $\begin{array}{l}\text { The United Nations Environment } \\
\text { Programme (UNEP) }\end{array}$ & $\begin{array}{l}\text { - Organisation aiming to develop international environmental agreements } \\
\text { on climate change, management of marine and terrestrial ecosystems } \\
\text { (including inland waters) and green economic development. }\end{array}$ \\
\hline 1973 & $\begin{array}{l}\text { Convention on International Trade in } \\
\text { Endangered Species of Wild Fauna } \\
\text { and Flora (CITES) }\end{array}$ & $\begin{array}{l}\text { - One of the oldest conservation agreements still in action; it came into } \\
\text { force in } 1975 \text {. } \\
\text { Mainly to protect plants and animals at risk of extinction and ensure that } \\
\text { international trade in wild specimens does not threaten their survival in } \\
\text { the wild. }\end{array}$ \\
\hline 1982 & The World Resources Institute (WRI) & $\begin{array}{l}\text { - Comprised by local and national governments alongside with private } \\
\text { and public corporations. } \\
\text { - Offer information on global climate change issues, sustainable markets, } \\
\text { ecosystem protection and environmental governance services. }\end{array}$ \\
\hline 1988 & $\begin{array}{l}\text { Intergovernmental Panel on Climate } \\
\text { Change (IPCC) }\end{array}$ & $\begin{array}{l}\text { - One of the United Nation's intergovernmental bodies. } \\
\text { Responsible for compiling knowledge on human-induced climate change, } \\
\text { providing scientific information of the impacts on the natural, political } \\
\text { and economic sectors. }\end{array}$ \\
\hline 1991 * & World Water Week & $\begin{array}{l}\text { - Non-profit annual event on global water issues, organised by Stockholm } \\
\text { International Water Institute. } \\
\text { Responsible to find solutions to the water-related challenges through } \\
\text { partnerships with organisations from various countries and sectors. }\end{array}$ \\
\hline 1992 & $\begin{array}{l}\text { Earth Summit-Convention on } \\
\text { Biological Diversity (CBD) }\end{array}$ & $\begin{array}{l}\text { Event held in Rio de Janeiro; it came into force in 1993, establishing a } \\
\text { multilateral treaty (CBD). } \\
\text { Target the conservation of biodiversity in all its aspects, sustainable use of } \\
\text { nature components and fair sharing of benefits arising from } \\
\text { genetic resources. }\end{array}$ \\
\hline
\end{tabular}


Table 1. Cont.

\begin{tabular}{|c|c|c|}
\hline Year & Milestone & Conservation Strategies \\
\hline 2000 & The Cartagena Protocol & $\begin{array}{l}\text { - A protocol that arises as a supplementary agreement to the CBD (1992). } \\
\text { - Aim to guarantee biosafety in the movements of living modified } \\
\text { organisms (LMOs) between countries; it entered into force in } 2003 \text {. }\end{array}$ \\
\hline 2000 & $\begin{array}{l}\text { The Millennium Development } \\
\text { Goals (MDGs) }\end{array}$ & $\begin{array}{l}\text { - } \quad \text { Comprises eight international development goals. } \\
\text { Focus mainly on human population needs, only goal 7, targeted to ensure } \\
\text { environmental sustainability by } 2015 \text {. }\end{array}$ \\
\hline $\begin{array}{l}2001- \\
2005\end{array}$ & $\begin{array}{l}\text { The Millennium Ecosystem } \\
\text { Assessment (MEA) }\end{array}$ & $\begin{array}{l}\text { - Comprehensive assessment, targeting the consequences of ecosystems } \\
\text { changes due to anthropogenic activities as well as establishing scientific } \\
\text { basis for the development of conservation and sustainable development. }\end{array}$ \\
\hline 2002 & $\begin{array}{l}\text { The World Summit on Sustainable } \\
\text { Development }\end{array}$ & $\begin{array}{l}\text { - Held in Johannesburg ("Rio }+10 \text { "), it united heads of state, delegates, } \\
\text { - } \quad \text { Address the improvement of people's lives while conserving nature in a } \\
\text { world with a growing population and ever-increasing resource demands. }\end{array}$ \\
\hline 2002 & $\begin{array}{l}\text { Strategic Plan for the Convention on } \\
\text { Biological Diversity }\end{array}$ & $\begin{array}{l}\text { A new strategic plan to effectively halt the loss of biodiversity and secure } \\
\text { the continuity of its beneficial uses through the conservation and } \\
\text { sustainable use of its components. } \\
\text { Raise the concern of fair and equitable sharing of benefits arising from } \\
\text { novel genetic resources. }\end{array}$ \\
\hline 2010 & $\begin{array}{l}\text { The United Nations World Water } \\
\text { Development Report (WWDR) }\end{array}$ & $\begin{array}{l}\text { - The UN-Water's report tackling water demand and sanitation issues, } \\
\text { published by UNESCO. } \\
\text { It provides insights and knowledge concerning the state, use and } \\
\text { management of freshwaters, as well as formulation and implementation } \\
\text { of sustainable water policies. }\end{array}$ \\
\hline 2010 & $\begin{array}{l}\text { Strategic Plan for Biodiversity } \\
\text { Revision 2011-2020 }\end{array}$ & $\begin{array}{l}\text { - Held in Nagoya, Japan, the meeting updated the Strategic Plan for } \\
\text { Biodiversity for the 2011-2020 period, providing a framework on } \\
\text { biodiversity for the UN and partners engaged in } \\
\text { biodiversity management. } \\
\text { Resulted in the signature of the Nagoya Protocol and the development of } \\
\text { the Aichi Biodiversity Target. }\end{array}$ \\
\hline 2010 & The Nagoya Protocol & $\begin{array}{l}\text { - A supplementary agreement to the CBD (1992). } \\
\text { To target the implementation of one from the three objectives of the CBD: } \\
\text { the fair and equitable sharing of benefits arising out of the utilisation of } \\
\text { genetic resources, setting out obligations for its contracting parties. }\end{array}$ \\
\hline 2010 & The Aichi Biodiversity Targets & $\begin{array}{l}\text { A } 10 \text {-year plan, created by the CDB parties, sub-divided into } 20 \text { targets, } \\
\text { aiming to protect and conserve natural systems. }\end{array}$ \\
\hline 2010 & $\begin{array}{l}\text { The Intergovernmental Science-Policy } \\
\text { Platform on Biodiversity and } \\
\text { Ecosystem Services (IPBES) }\end{array}$ & $\begin{array}{l}\text { - Intergovernmental organisation established to improve the interface } \\
\text { between science and politics on issues of biodiversity and } \\
\text { ecosystem services. } \\
\text { - It entered into force in } 2013 \text {. }\end{array}$ \\
\hline 2012 & $\begin{array}{l}\text { The world's } 100 \text { most } \\
\text { threatened species }\end{array}$ & $\begin{array}{l}\text { - IUCN report with the } 100 \text { most threatened species was published by the } \\
\text { Zoological Society of London as a book, named Priceless or Worthless? } \\
\text { - The list contain species threatened of extinction, stressing that 'all species } \\
\text { have an inherent right to exist'. }\end{array}$ \\
\hline 2015 & $\begin{array}{l}\text { Sustainable Development } \\
\text { Goals (SDGs) }\end{array}$ & $\begin{array}{l}\text { - Developed by the UN to replace the MDGs. } \\
\text { The SDGs run from } 2015 \text { to 2030, setting a 15-year plan to achieve } 17 \\
\text { goals, aiming to end poverty, protect the planet and improve the quality } \\
\text { of life on earth. }\end{array}$ \\
\hline
\end{tabular}


Table 1. Cont.

\begin{tabular}{|c|c|c|}
\hline Year & Milestone & Conservation Strategies \\
\hline 2020 & $\begin{array}{l}\text { Post-2020 Global } \\
\text { Biodiversity Framework }\end{array}$ & $\begin{array}{l}\text { - Reinforces the 2001-2020 strategic plan; it stipulates ambitious goals to } \\
\text { generate a renovation in society's relationship with biodiversity, ensuring } \\
\text { people are 'living in harmony with nature' by } 2050 \text {. }\end{array}$ \\
\hline 2020 & $\begin{array}{l}\text { The UN Decade on } \\
\text { Ecosystem Restoration }\end{array}$ & $\begin{array}{l}\text { - A call to protect ecosystems around the world, aiming to halt their } \\
\text { degradation, and implement restoration practices. } \\
\text { The UN Decade runs from } 2021 \text { to 2030, which is also the deadline for } \\
\text { the SDGs. }\end{array}$ \\
\hline 2021 & Water and Climate Pavilion at COP 26 & $\begin{array}{l}\text { - Held in Glasgow, the COP } 26 \text { (Convention of the Parties) led efforts to } \\
\text { mobilise the water and global climate action communities to launch the } \\
\text { first Water and Climate Pavilion in the history of the convention. }\end{array}$ \\
\hline $2021 *$ & Water at the IUCN Congress & $\begin{array}{l}\text { - For the first time, freshwater was featured as its own thematic focus at } \\
\text { the IUCN Congress. }\end{array}$ \\
\hline
\end{tabular}

${ }^{*}$ Milestone focussing directly on freshwaters.

The IUCN, founded in 1948, was the first global authority dedicated to nature protection and conservation. Later, several other environmental organisations emerged, such as Worldwide Fund for Nature (WWF; 1961) and Green Peace (1971) (Table 1). One interesting milestone was the Ramsar Convention (1971), the first international agreement related to freshwaters aiming to protect wetlands (Table 1). Especially in the freshwater conservation strategies, there is a tendency to embrace only the social benefits to humans, such as ceasing poverty, hunger, or diseases and economically beneficial macrofauna. Given the current mindset, aquatic fungi, particularly aquatic hyphomycetes, are likely to be neglected, disregarding their key ecological role to sustain freshwater ecosystems.

\section{Conclusions}

It is time to embrace aquatic hyphomycetes in conservation strategies, as emphasised in this review (Figure 2). The biggest challenge is to foster global partnerships via research projects, which may unlock funds for global surveys and educational programs, thereby attracting more audience and media attention $[105,106]$. Ideally, government, policymakers, scientists, ecosystem managers, non-governmental organisations and citizens should combine efforts to exploit the aquatic fungi to protect freshwater ecosystems and the services they provide [107]. This calls for a robust biodiversity database across the globe, which may promote their access to conservation strategies. 


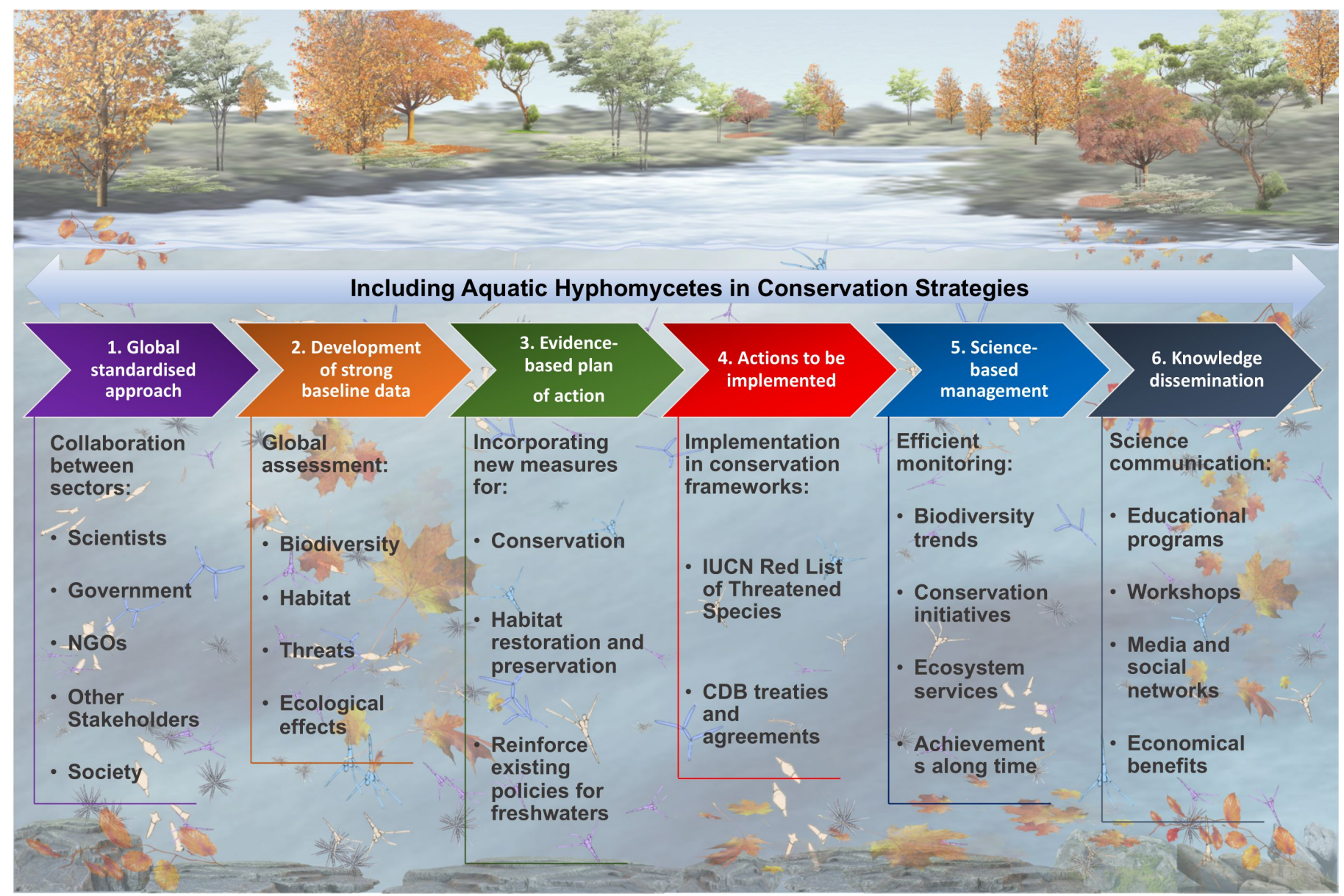

Figure 2. A comprehensive strategy for the conservation of aquatic hyphomycetes across the globe.

Author Contributions: J.B. wrote sections of the first draft, reviewed and edited. S.S. conceived the review, wrote sections of first draft, structured, reviewed and edited. All authors have read and agreed to the published version of the manuscript.

Funding: This study is financed by the Portuguese Foundation for Science and Technology (FCT) within the scope of the projects UIDB/04292/2020 granted to Marine and Environmental Sciences Centre (MARE). Associação para a Promoção do Conhecimento em Ecologia Aquática (PROAQUA) is acknowledged for supporting J. Barros and the University of Coimbra S. is acknowledged for the contract (IT057-18-7254) by S. Seena.

Conflicts of Interest: The authors declare no conflict of interest.

\section{References}

1. Shiklomanov, I.A. World Fresh Water Resource. In Water Crisis: A Guide to World Fresh Water Resources; Gleick, P.H., Ed.; Oxford University Press: Oxford, UK, 1993.

2. $\quad$ Dudgeon, D.; Arthington, A.H.; Gessner, M.O.; Kawabata, Z.-I.; Knowler, D.J.; Lévêque, C.; Naiman, R.J.; Prieur-Richard, A.-H.; Soto, D.; Stiassny, M.L.J.; et al. Freshwater Biodiversity: Importance, Threats, Status and Conservation Challenges. Biol. Rev. 2006, 81, 163-182. [CrossRef]

3. Gleick, P.H. Basic Water Requirements for Human Activities: Meeting Basic Needs. Water Int. 1996, 21, 83-92. [CrossRef]

4. Garcia-Moreno, J.; Harrison, I.J.; Dudgeon, D.; Clausnitzer, V.; Darwall, W.; Farrell, T.; Savy, C.; Tockner, K.; Tubbs, N. Sustaining Freshwater Biodiversity in the Anthropocene BT. In The Global Water System in the Anthropocene: Challenges for Science and Governance; Bhaduri, A., Bogardi, J., Leentvaar, J., Marx, S., Eds.; Springer: Berlin/Heidelberg, Germany, 2014; pp. 247-270. ISBN 978-3-319-07548-8.

5. Dudgeon, D. Multiple Threats Imperil Freshwater Biodiversity in the Anthropocene. Curr. Biol. 2019, 29, R960-R967. [CrossRef] [PubMed] 
6. Sachs, J.; Kroll, C.; Lafortune, G.; Fuller, G.; Woelm, F. The Sustainable Development Goals Report 2021; Cambridge University Press: Cambridge, UK, 2021.

7. Naeem, S.; Chazdon, R.; Duffy, J.E.; Prager, C.; Worm, B. Biodiversity and Human Well-Being: An Essential Link for Sustainable Development. Proc. R. Soc. B Biol. Sci. 2016, 283, 20162091. [CrossRef] [PubMed]

8. Almond, R.E.A.; Grooten, M.; Peterson, T. Living Planet Report 2020-Bending the Curve of Biodiversity Loss; World Wildlife Fund: Gland, Switzerland, 2020.

9. Flitcroft, R.; Cooperman, M.S.; Harrison, I.J.; Juffe-Bignoli, D.; Boon, P.J. Theory and Practice to Conserve Freshwater Biodiversity in the Anthropocene. Aquat. Conserv. Mar. Freshw. Ecosyst. 2019, 29, 1013-1021. [CrossRef]

10. Grill, G.; Lehner, B.; Thieme, M.; Geenen, B.; Tickner, D.; Antonelli, F.; Babu, S.; Borrelli, P.; Cheng, L.; Crochetiere, H.; et al. Mapping the World's Free-Flowing Rivers. Nature 2019, 569, 215-221. [CrossRef] [PubMed]

11. Arthington, A.H. Grand Challenges to Support the Freshwater Biodiversity Emergency Recovery Plan. Front. Environ. Sci. 2021, 9, 118. [CrossRef]

12. Reid, A.J.; Carlson, A.K.; Creed, I.F.; Eliason, E.J.; Gell, P.A.; Johnson, P.T.J.; Kidd, K.A.; MacCormack, T.J.; Olden, J.D.; Ormerod, S.J.; et al. Emerging Threats and Persistent Conservation Challenges for Freshwater Biodiversity. Biol. Rev. 2019, 94, 849-873. [CrossRef]

13. Milardi, M.; Gavioli, A.; Soininen, J.; Castaldelli, G. Exotic Species Invasions Undermine Regional Functional Diversity of Freshwater Fish. Sci. Rep. 2019, 9, 17921. [CrossRef]

14. Senn-Irlet, B.; Heilmann-Clausen, J.; Genney, D.; Dahlberg, A. Guidance for Conservation of Macrofungi in Europe; ECCF: Strasbourg, France, 2007.

15. Li, D.-W. Biology of Microfungi; Springer: Berlin/Heidelberg, Germany, 2016; Volume 146.

16. Ingold, C.T. Aquatic Hyphomycetes of Decaying Alder Leaves. Trans. Br. Mycol. Soc. 1942, 25, 339-417. [CrossRef]

17. Hynes, H.B.N. The Ecology of Running Waters; Liverpool University Press: Liverpool, UK, 1970; Volume 555.

18. Graça, M.A.S. The Role of Invertebrates on Leaf Litter Decomposition in Streams-A Review. Int. Rev. Hydrobiol. 2001, 86, 383-393. [CrossRef]

19. Graça, M.A.S.; Canhoto, C. Leaf Litter Processing in Low Order Streams. Limnetica 2006, 25, 1-10. [CrossRef]

20. Duarte, S.; Bärlocher, F.; Pascoal, C.; Cássio, F. Biogeography of Aquatic Hyphomycetes: Current Knowledge and Future Perspectives. Fungal Ecol. 2016, 19, 169-181. [CrossRef]

21. Shearer, C.A.; Descals, E.; Kohlmeyer, B.; Kohlmeyer, J.; Marvanová, L.; Padgett, D.; Porter, D.; Raja, H.A.; Schmit, J.P.; Thorton, H.A.; et al. Fungal Biodiversity in Aquatic Habitats. Biodivers. Conserv. 2007, 16, 49-67. [CrossRef]

22. Duarte, S.; Pascoal, C.; Cássio, F.; Bärlocher, F. Aquatic Hyphomycete Diversity and Identity Affect Leaf Litter Decomposition in Microcosms. Oecologia 2006, 147, 658-666. [CrossRef] [PubMed]

23. Seena, S.; Casotti, C.; Cornut, J. Inter- and Intraspecific Functional Variability of Aquatic Fungal Decomposers and Freshwater Ecosystem Processes. Sci. Total Environ. 2020, 707, 135570. [CrossRef]

24. Handa, I.T.; Aerts, R.; Berendse, F.; Berg, M.P.; Bruder, A.; Butenschoen, O.; Chauvet, E.; Gessner, M.O.; Jabiol, J.; Makkonen, M.; et al. Consequences of Biodiversity Loss for Litter Decomposition across Biomes. Nature 2014, 509, 218-221. [CrossRef]

25. Boyero, L.; Pearson, R.G.; Gessner, M.O.; Barmuta, L.A.; Ferreira, V.; Graça, M.A.S.; Dudgeon, D.; Boulton, A.J.; Callisto, M.; Chauvet, E.; et al. A Global Experiment Suggests Climate Warming Will Not Accelerate Litter Decomposition in Streams but Might Reduce Carbon Sequestration. Ecol. Lett. 2011, 14, 289-294. [CrossRef]

26. Gessner, M.O.; Swan, C.M.; Dang, C.K.; McKie, B.G.; Bardgett, R.D.; Wall, D.H.; Hättenschwiler, S. Diversity Meets Decomposition Trends Ecol. Evol. 2010, 25, 372-380. [CrossRef]

27. Gessner, M.O.; Chauvet, E. A Case for Using Litter Breakdown to Assess Functional Stream Integrity. Ecol. Appl. 2002, 12, 498-510. [CrossRef]

28. Young, R.G.; Matthaei, C.D.; Townsend, C.R. Organic Matter Breakdown and Ecosystem Metabolism: Functional Indicators for Assessing River Ecosystem Health. J. N. Am. Benthol. Soc. 2008, 27, 605-625. [CrossRef]

29. Water, U.N. The United Nations World Water Development Report 2021: Valuing Water; UNESCO: Paris, France, 2021.

30. 2030 Water Resources Group. Charting Our Water Future Economic Frameworks to Inform Decision-Making; McKinsey \& Company: Hong Kong, China, 2009.

31. Alcamo, J. Environmental Futures: The Practice of Environmental Scenario Analysis; Elsevier: Amsterdam, The Netherlands, 2008.

32. Covich, A.P.; Austen, M.C.; BÄRlocher, F.; Chauvet, E.; Cardinale, B.J.; Biles, C.L.; Inchausti, P.; Dangles, O.; Solan, M.; Gessner, M.O.; et al. The Role of Biodiversity in the Functioning of Freshwater and Marine Benthic Ecosystems. BioScience 2004, 54, 767-775. [CrossRef]

33. Chauvet, E.; Cornut, J.; Sridhar, K.R.; Selosse, M.-A.; Bärlocher, F. Beyond the Water Column: Aquatic Hyphomycetes Outside Their Preferred Habitat. Fungal Ecol. 2016, 19, 112-127. [CrossRef]

34. Pascoal, C.C.; Marvanová, L. Anthropogenic Stress May Affect Aquatic Hyphomycete Diversity More than Leaf Decomposition in a Low-Order Stream. Arch. Für Hydrobiol. 2005, 162, 481-496. [CrossRef]

35. Solé, M.; Fetzer, I.; Wennrich, R.; Sridhar, K.R.; Harms, H.; Krauss, G. Aquatic Hyphomycete Communities as Potential Bioindicators for Assessing Anthropogenic Stress. Sci. Total Environ. 2008, 389, 557-565. [CrossRef] [PubMed] 
36. Junk, W.J.; An, S.; Finlayson, C.M.; Gopal, B.; Květ, J.; Mitchell, S.A.; Mitsch, W.J.; Robarts, R.D. Current State of Knowledge Regarding the World's Wetlands and Their Future under Global Climate Change: A Synthesis. Aquat. Sci. 2013, 75, 151-167. [CrossRef]

37. Poff, N.L.; Allan, J.D.; Bain, M.B.; Karr, J.R.; Prestegaard, K.L.; Richter, B.D.; Sparks, R.E.; Stromberg, J.C.; Junk, W.J.; An, S.; et al. The Impact of Climate Change on Freshwater Ecosystems Due to Altered River Flow Regimes. Nature 2010, 47, 1929. Available online: https://www.fs.fed.us/stream/Poffetal_1997.pdf (accessed on 29 December 2021).

38. Chao, B.F.; Wu, Y.H.; Li, Y.S. Impact of Artificial Reservoir Water Impoundment on Global Sea Level. Science 2008, 320, $212-214$. [CrossRef]

39. Phung, D.; Nguyen-Huy, T.; Tran, N.N.; Tran, D.N.; Doan, V.Q.; Nghiem, S.; Nguyen, N.H.; Nguyen, T.H.; Bennett, T. Hydropower Dams, River Drought and Health Effects: A Detection and Attribution Study in the Lower Mekong Delta Region. Clim. Risk Manag. 2021, 32, 100280. [CrossRef]

40. Matthews, N. People and Fresh Water Ecosystems: Pressures, Responses and Resilience. Aquat. Procedia 2016, 6, 99-105. [CrossRef]

41. Colas, F.; Baudoin, J.-M.; Chauvet, E.; Clivot, H.; Danger, M.; Guérold, F.; Devin, S. Dam-Associated Multiple-Stressor Impacts on Fungal Biomass and Richness Reveal the Initial Signs of Ecosystem Functioning Impairment. Ecol. Indic. 2016, 60, 1077-1090. [CrossRef]

42. Martínez, A.; Larrañaga, A.; Basaguren, A.; Pérez, J.; Mendoza-Lera, C.; Pozo, J. Stream Regulation by Small Dams Affects Benthic Macroinvertebrate Communities: From Structural Changes to Functional Implications. Hydrobiologia 2013, 711, 31-42. [CrossRef]

43. Ferreira, V.; Koricheva, J.; Pozo, J.; Graça, M.A.S. A Meta-Analysis on the Effects of Changes in the Composition of Native Forests on Litter Decomposition in Streams. For. Ecol. Manag. 2016, 364, 27-38. [CrossRef]

44. Boyero, L.; Pearson, R.G.; Hui, C.; Gessner, M.O.; Pérez, J.; Alexandrou, M.A.; Graça, M.A.S.; Cardinale, B.J.; Albariño, R.J.; Arunachalam, M.; et al. Biotic and Abiotic Variables Influencing Plant Litter Breakdown in Streams: A Global Study. Proc. R. Soc. B 2016, 283, 20152664. [CrossRef]

45. Pimentel, D.; Berger, B.; Filiberto, D.; Newton, M.; Wolfe, B.; Karabinakis, E.; Clark, S.; Poon, E.; Abbett, E.; Nandagopal, S. Water Resources: Agricultural and Environmental Issues. BioScience 2004, 54, 909-918. [CrossRef]

46. Pérez, J.; Martínez, A.; Descals, E.; Pozo, J. Responses of Aquatic Hyphomycetes to Temperature and Nutrient Availability: A Cross-Transplantation Experiment. Microb. Ecol. 2018, 76, 328-339. [CrossRef]

47. Gulis, V.; Ferreira, V.; Graça, M.A.S. Stimulation of Leaf Litter Decomposition and Associated Fungi and Invertebrates by Moderate Eutrophication: Implications for Stream Assessment. Freshw. Biol. 2006, 51, 1655-1669. [CrossRef]

48. Wilcox, H.S.; Bruce Wallace, J.; Meyer, J.L.; Benstead, J.P. Effects of Labile Carbon Addition on a Headwater Stream Food Web. Limnol. Oceanogr. 2005, 50, 1300-1312. [CrossRef]

49. Ferreira, V.; Graça, M.A.S. Fungal Activity Associated with Decomposing Wood Is Affected by Nitrogen Concentration in Water. Int. Rev. Hydrobiol. 2007, 92, 1-8. [CrossRef]

50. Chandrashekar, K.R.; Kaveriappa, K.M. Effect of Pesticides on the Growth of Aquatic Hyphomycetes. Toxicol. Lett. 1989, 48, 311-315. [CrossRef]

51. Martínez, A.; Barros, J.; Gonçalves, A.L.; Canhoto, C. Salinisation Effects on Leaf Litter Decomposition in Fresh Waters: Does the Ionic Composition of Salt Matter? Freshw. Biol. 2020, 65, 1475-1483. [CrossRef]

52. Sridhar, K.R.; Duarte, S.; Cássio, F.; Pascoal, C. The Role of Early Fungal Colonizers in Leaf-Litter Decomposition in Portuguese Streams Impacted by Agricultural Runoff. Int. Rev. Hydrobiol. 2009, 94, 399-409. [CrossRef]

53. Bull, J.W.; Maron, M. How Humans Drive Speciation as Well as Extinction. Proc. R. Soc. B Biol. Sci. 2016, 283, 20160600. [CrossRef]

54. Canhoto, C.; Graça, M.A.S. Decomposition of Eucalyptus Globulus Leaves and Three Native Leaf Species (Alnus glutinosa, Castanea sativa and Quercus faginea) in a Portuguese Low Order Stream. Hydrobiologia 1996, 333, 79-85. [CrossRef]

55. Ferreira, V.; Elosegi, A.; Gulis, V.; Pozo, J.; Graça, M.A.S. Eucalyptus Plantations Affect Fungal Communities Associated with Leaf-Litter Decomposition in Iberian Streams. Arch. Für Hydrobiol. 2006, 166, 467-490. [CrossRef]

56. Pereira, A.; Ferreira, V. Invasion of Native Riparian Forests by Acacia Species Affects In-Stream Litter Decomposition and Associated Microbial Decomposers. Microb. Ecol. 2021, 81, 14-25. [CrossRef] [PubMed]

57. Leuzinger, S.; Rewald, B. The Who or the How? Species vs. Ecosystem Function Priorities in Conservation Ecology. Front. Plant Sci. 2021, 12, 2442. [CrossRef]

58. Steiner, F.M.; Schlick-Steiner, B.C.; VanDerWal, J.; Reuther, K.D.; Christian, E.; Stauffer, C.; Suarez, A.V.; Williams, S.E.; Crozier, R.H. Combined Modelling of Distribution and Niche in Invasion Biology: A Case Study of Two Invasive Tetramorium Ant Species. Divers. Distrib. 2008, 14, 538-545. [CrossRef]

59. Döll, P.; Bunn, S.E. The Impact of Climate Change on Freshwater Ecosystems Due to Altered River Flow Regimes. Clim. Chang. 2010, 14, 143-146. [CrossRef]

60. Singh, G.; Singh, A.; Singh, P.; Mishra, V.K. Chapter 4-Impact of Climate Change on Freshwater Ecosystem. In Water Conservation in the Era of Global Climate Change; Thokchom, B., Qiu, P., Singh, P., Iyer, P.K., Eds.; Elsevier: Amsterdam, The Netherlands, 2021; pp. 73-98. ISBN 978-0-12-820200-5.

61. Kumaraswamy, T.R.; Javeed, S.; Javaid, M.; Naika, K. Impact of Pollution on Quality of Freshwater Ecosystems. In Fresh Water Pollution Dynamics and Remediation; Springer: Berlin/Heidelberg, Germany, 2020; pp. 69-81.

62. Vörösmarty, C.J.; McIntyre, P.B.; Gessner, M.O.; Dudgeon, D.; Prusevich, A.; Green, P.; Glidden, S.; Bunn, S.E.; Sullivan, C.A.; Liermann, C.R.; et al. Global Threats to Human Water Security and River Biodiversity. Nature 2010, 467, 555-561. [CrossRef] 
63. Ferreira, V.; Voronina, E. Impact of Climate Change on Aquatic Hyphomycetes and Terrestrial Macromycetes. Clim. Chang. Microb. Ecol. Curr. Res. Future Trends 2016, 53-72. [CrossRef]

64. Krauss, G.-J.; Solé, M.; Krauss, G.; Schlosser, D.; Wesenberg, D.; Bärlocher, F. Fungi in Freshwaters: Ecology, Physiology and Biochemical Potential. FEMS Microbiol. Rev. 2011, 35, 620-651. [CrossRef] [PubMed]

65. Seena, S.; Bärlocher, F.; Sobral, O.; Gessner, M.O.; Dudgeon, D.; McKie, B.G.; Chauvet, E.; Boyero, L.; Ferreira, V.; Frainer, A.; et al. Biodiversity of Leaf Litter Fungi in Streams along a Latitudinal Gradient. Sci. Total Environ. 2019, 661, 306-315. [CrossRef] [PubMed]

66. Ferreira, V.; Gulis, V.; Pascoal, C.; Graça, M.A.S. Chapter 18. Stream Pollution and Fungi. In Freshwater Fungi; De Gruyter: Berlin, Germany, 2014; pp. 389-412.

67. Woodward, G.; Bonada, N.; Feeley, H.B.; Giller, P.S. Resilience of a Stream Community to Extreme Climatic Events and Long-Term Recovery from a Catastrophic Flood. Freshw. Biol. 2015, 60, 2497-2510. [CrossRef]

68. Evangeliou, N.; Grythe, H.; Klimont, Z.; Heyes, C.; Eckhardt, S.; Lopez-Aparicio, S.; Stohl, A. Atmospheric Transport Is a Major Pathway of Microplastics to Remote Regions. Nat. Commun. 2020, 11, 3381. [CrossRef]

69. Du, J.; Qv, W.; Niu, Y.; Yuan, S.; Zhang, L.; Yang, H.; Zhang, Y. Co-Exposures of Acid Rain and ZnO Nanoparticles Accelerate Decomposition of Aquatic Leaf Litter. J. Hazard. Mater. 2022, 426, 128141. [CrossRef]

70. Niyogi, D.K.; Lewis, W.M., Jr.; McKnight, D.M. Litter Breakdown in Mountain Streams Affected by Mine Drainage: Biotic Mediation of Abiotic Controls. Ecol. Appl. 2001, 11, 506-516. [CrossRef]

71. Sridhar, K.R.; Raviraja, N.S. Aquatic Hyphomycetes and Leaf Litter Processing in Polluted and Unpolluted. In Trichomycetes and Other Fungal Groups; CRC Press: Boca Raton, FL, USA, 2001; p. 293.

72. Guimarães-Soares, L.; Felícia, H.; João Bebianno, M.; Cássio, F. Metal-Binding Proteins and Peptides in the Aquatic Fungi Fontanospora fusiramosa and Flagellospora curta Exposed to Severe Metal Stress. Sci. Total Environ. 2006, 372, 148-156. [CrossRef]

73. Azevedo, M.M.; Cássio, F. Effects of Metals on Growth and Sporulation of Aquatic Fungi. Drug Chem. Toxicol. 2010, 33, 269-278. [CrossRef]

74. Miersch, J.; Tschimedbalshir, M.; Bärlocher, F.; Grams, Y.; Pierau, B.; Schierhorn, A.; Krauss, G.-J. Heavy Metals and Thiol Compounds in Mucor Racemosus and Articulospora Tetracladia. Mycol. Res. 2001, 105, 883-889. [CrossRef]

75. Seena, S.; Kumar, S. Short-Term Exposure to Low Concentrations of Copper Oxide Nanoparticles Can Negatively Impact the Ecological Performance of a Cosmopolitan Freshwater Fungus. Environ. Sci. Processes Impacts 2019, 21, 2001-2007. [CrossRef] [PubMed]

76. Seena, S.; Sobral, O.; Cano, A. Metabolomic, Functional, and Ecologic Responses of the Common Freshwater Fungus Neonectria Lugdunensis to Mine Drainage Stress. Sci. Total Environ. 2020, 718, 137359. [CrossRef] [PubMed]

77. Abel, T.H.; Bärlocher, F. Effects of Cadmium on Aquatic Hyphomycetes. Appl. Environ. Microbiol. 1984, 48, 245-251. [CrossRef]

78. Jaeckel, P.; Krauss, G.-J.; Krauss, G. Cadmium and Zinc Response of the Fungi Heliscus lugdunensis and Verticillium Cf. Alboatrum Isolated from Highly Polluted Water. Sci. Total Environ. 2005, 346, 274-279. [CrossRef]

79. Miersch, J.; Bärlocher, F.; Bruns, I. Effects of Cadmium, Copper, and Zinc on Growth and Thiol Content of Aquatic Hyphomycetes. Hydrobiologia 1997, 346, 77-84. [CrossRef]

80. Soares, A.; Guieysse, B.; Jefferson, B.; Cartmell, E.; Lester, J.N. Nonylphenol in the Environment: A Critical Review on Occurrence, Fate, Toxicity and Treatment in Wastewaters. Environ. Int. 2008, 34, 1033-1049. [CrossRef] [PubMed]

81. Vazquez-Duhalt, R.; Marquez-Rocha, F.; Ponce, E.; Licea, A.F.; Viana, M.T. Nonylphenol, an Integrated Vision of a Pollutant. Appl. Ecol. Environ. Res. 2005, 4, 1-25. [CrossRef]

82. Bärlocher, F.; Guenzel, K.; Sridhar, K.R.; Duffy, S.J. Effects of 4-n-Nonylphenol on Aquatic Hyphomycetes. Sci. Total Environ. 2011, 409, 1651-1657. [CrossRef]

83. Adetunde, L.A.; Glover, R.L.K. Bacteriological Quality of Borehole Water Used by Students of University for Development Studies, Navrongo Campus in Upper-East Region of Ghana. Curr. Res. J. Biol. Sci. 2010, 2, 361-364.

84. Kuburić, M. Tolerance and Co-Tolerance of Microbial Communities on Leaf Litter to Silver Nanoparticles and Antibiotics. Ph.D. Thesis, Universidade de Coimbra, Coimbra, Portugal, 2014.

85. Tickner, D.; Opperman, J.J.; Abell, R.; Acreman, M.; Arthington, A.H.; Bunn, S.E.; Cooke, S.J.; Dalton, J.; Darwall, W.; Edwards, G.; et al. Bending the Curve of Global Freshwater Biodiversity Loss: An Emergency Recovery Plan. BioScience 2020, 70, 330-342. [CrossRef]

86. Vallero, D.A. Chapter 20-Thermal Pollution. In Waste, 2nd ed.; Letcher, T.M., Vallero, D.A.B.T.-W., Eds.; Academic Press: New York, NY, USA, 2019; pp. 381-404. ISBN 978-0-12-815060-3.

87. Pradhan, A.; Seena, S.; Pascoal, C.; Cássio, F. Can Metal Nanoparticles Be a Threat to Microbial Decomposers of Plant Litter in Streams? Microb. Ecol. 2011, 62, 58-68. [CrossRef] [PubMed]

88. Pradhan, A.; Seena, S.; Dobritzsch, D.; Helm, S.; Gerth, K.; Dobritzsch, M.; Krauss, G.-J.; Schlosser, D.; Pascoal, C.; Cássio, F. Physiological Responses to NanoCuO in Fungi from Non-Polluted and Metal-Polluted Streams. Sci. Total Environ. 2014, 466-467, 556-563. [CrossRef] [PubMed]

89. Barros, J.; Seena, S. Plastisphere in Freshwaters: An Emerging Concern. Environ. Pollut. 2021, 290, 118123. [CrossRef] [PubMed]

90. Seena, S.; Gutiérrez, I.B.; Barros, J.; Nunes, C.; Marques, J.C.; Kumar, S.; Gonçalves, A.M.M. Impacts of Low Concentrations of Nanoplastics on Leaf Litter Decomposition and Food Quality for Detritivores in Streams. J. Hazard. Mater. 2022, 429, 128320. [CrossRef] 
91. Balian, E.V.; Segers, H.; Lévèque, C.; Martens, K. The Freshwater Animal Diversity Assessment: An Overview of the Results. Hydrobiologia 2008, 595, 627-637. [CrossRef]

92. Mougi, A.; Kondoh, M. Diversity of Interaction Types and Ecological Community Stability. Science 2012, 337, 349-351. [CrossRef]

93. Tedesco, P.A.; Beauchard, O.; Bigorne, R.; Blanchet, S.; Buisson, L.; Conti, L.; Cornu, J.-F.; Dias, M.S.; Grenouillet, G.; Hugueny, B.; et al. A Global Database on Freshwater Fish Species Occurrence in Drainage Basins. Sci. Data 2017, 4, 170141. [CrossRef]

94. Darwall, W.R.T.; Holland, R.A.; Smith, K.G.; Allen, D.; Brooks, E.G.E.; Katarya, V.; Pollock, C.M.; Shi, Y.; Clausnitzer, V.; Cumberlidge, N.; et al. Implications of Bias in Conservation Research and Investment for Freshwater Species. Conserv. Lett. 2011, 4, 474-482. [CrossRef]

95. Darwall, W.; Smith, K.; Allen, D.; Seddon, M.; Reid, G.M.; Clausnitzer, V.; Kalkman, V. Freshwater Biodiversity: A Hidden Resource under Threat. In Wildlife in a Changing World: An Analysis of the 2008 IUCN Red List of Threatened Species; IUCN: Gland, Switzerland, 2009; pp. 43-53.

96. Anderson, J.L.; Shearer, C.A. Population Genetics of the Aquatic Fungus Tetracladium Marchalianum over Space and Time. PLoS ONE 2011, 6, e15908. [CrossRef]

97. Jabiol, J.; Bruder, A.; Gessner, M.O.; Makkonen, M.; McKie, B.G.; Peeters, E.T.H.M.; Vos, V.C.A.; Chauvet, E. Diversity Patterns of Leaf-Associated Aquatic Hyphomycetes along a Broad Latitudinal Gradient. Fungal Ecol. 2013, 6, 439-448. [CrossRef]

98. IUCN. The IUCN Red List of Threatened Species; IUCN: Grand, Swiss, 2021.

99. Goffeau, A.; Barrell, B.G.; Bussey, H.; Davis, R.W.; Dujon, B.; Feldmann, H.; Galibert, F.; Hoheisel, J.D.; Jacq, C.; Johnston, M.; et al. Life with 6000 Genes. Science 1996, 274, 546-567. [CrossRef] [PubMed]

100. Bonfante, P.; Anca, I.-A. Plants, Mycorrhizal Fungi, and Bacteria: A Network of Interactions. Annu. Rev. Microbiol. 2009, 63, 363-383. [CrossRef] [PubMed]

101. Smith, S.E.; Jakobsen, I.; Grønlund, M.; Smith, F.A. Roles of Arbuscular Mycorrhizas in Plant Phosphorus Nutrition: Interactions between Pathways of Phosphorus Uptake in Arbuscular Mycorrhizal Roots Have Important Implications for Understanding and Manipulating Plant Phosphorus Acquisition. Plant Physiol. 2011, 156, 1050-1057. [CrossRef] [PubMed]

102. Tittensor, D.P.; Walpole, M.; Hill, S.L.; Boyce, D.G.; Britten, G.L.; Burgess, N.D.; Butchart, S.H.; Leadley, P.W.; Regan, E.C.; Alkemade, R.; et al. A mid-term analysis of progress toward international biodiversity targets. Science 2014, 346, 241-244. [CrossRef] [PubMed]

103. Leadley, P.; Proença, V.; Fernández-Manjarrés, J.; Pereira, H.M.; Alkemade, R.; Biggs, R.; Bruley, E.; Cheung, W.; Cooper, D.; Figueiredo, J.; et al. Interacting Regional-Scale Regime Shifts for Biodiversity and Ecosystem Services. BioScience 2014, 64, 665-679. [CrossRef]

104. Jones, J.P.G.; Asner, G.P.; Butchart, S.H.M.; Karanth, K.U. The ‘Why', ‘What'and 'How'of Monitoring for Conservation. Key Top. Conserv. Biol. 2013, 2, 327-343. [CrossRef]

105. Strayer, D.L.; Dudgeon, D. Freshwater Biodiversity Conservation: Recent Progress and Future Challenges. J. N. Am. Benthol. Soc. 2010, 29, 344-358. [CrossRef] 
106. Gonçalves, S.C.; Haelewaters, D.; Furci, G.; Mueller, G.M. Include All Fungi in Biodiversity Goals. Science 2021, $373,403$. [CrossRef]

107. Mayers, J. Water Ecosystem Services and Poverty Under Climate Change: Key Issues and Research Priorities: Report of a Scoping Exercise to Help Develop a Research Programme for the UK Department for International Development; IIED: London, UK, 2009. 